AFRICAN

\title{
African soft power in China
}

\section{by Adams Bodomo*}

Department of African Studies, and Global African Diaspora Studies (GADS) Research Platform, University of Vienna

Vienna, Austria

\begin{abstract}
This paper comprises an account of outstanding performance by some Africans living in China in the practice of their professions, in their studies, in public service, and in their general interaction with the Chinese people and the Chinese state. The paper argues that these activities, recognised as outstanding by the Chinese and widely reported in the Chinese and international media, constitute the building blocks of African soft power in China. The consequences of this argumentation include the fact that if the governments of Africa and China want to promote peopleto-people relations in the third decade of $21^{\text {st }}$ Century Africa-China relations under the aegis of the Forum for Africa-China Cooperation (FOCAC), more of such activities by diaspora Africans in China and diaspora Chinese in Africa must be recognised, promoted, rewarded, and institutionalised within the formal FOCAC framework.
\end{abstract}

*Adams Bodomo is Professor of African Studies (holding the Chair of African Languages and Literatures) at the University of Vienna, Austria, where he directs a new research centre called the Global African Diaspora Studies (GADS) Research Platform. 
AFFAIRS

\section{Introduction}

After more than a decade (2000 to 2013) of intense co-operation between Africa and China within the framework of the Forum on Africa-China Cooperation (FOCAC), it is time to take stock of these relations and find ways to develop them further in the second and subsequent decades. In this paper, I shall briefly examine the role of Diaspora Africans in China and Diaspora Chinese in Africa with the aim of finding out if these diaspora groups can contribute to the development of Africa-China relations. There are now more than two million Chinese in Africa and half a million Africans in China; and many academic studies including journal articles, books and theses have already been produced on Africans in China (examples include: Bodomo 2009, 2010, 2012, 2013a and b, 2014; Bredeloup 2012; Bork et al. 2011; Castillo 2014; Cissé 2013; Hall et al. 2014; Han 2013; Haugen 2011, 2012, 2013; Lan 2014; Li et al. 2009, 2012; Lyons et al. 2008, 2012, 2013; McLaughlin 2014; Pieke 2012) and on Chinese in Africa (for example: Park 2008; Mohan and Lampert 2013; Sautman and Yan 2014).

These numbers are the basis of nascent diasporan communities on either side of the partnership; a Diasporan community being defined as a transnational or deterritorialised group of people organising themselves into networks or relating to themselves and to their host communities based on some common socio-cultural features and institutions like language, food, and clothing; and who have links, whether permanent or tenuous, back to their historical homelands. This diasporic presence on either side of the partnership is not without debate. What challenges do these Diasporas pose for their hosts and for general Africa-China relations? Do they play any positive roles and how can we further harness these positive roles to strengthen Africa-China cooperation? On the one hand there are media reports (for example CNN, BBC and SCMP) and academic analyses (for example Zhou, 2011; and Mathews and Yang 2012 for Africans in China; Mohan and Lampert 2013 for Chinese in Angola, Ghana and Nigeria; and Sautman and Yan 2014 for Africans in Zambia) that show that these communities indulge in activities that create negative perceptions, tensions and divisions and thus threaten the strengthening of relations between the two parties. There are, however, those that believe that diaspora 
AFRICAN

communities on either side of the partnership have a major role to play in developing stronger Africa-China cooperation (for example Bodomo 2010, 2012; Bodomo and Ma 2010, 2012; Bodomo and Silva 2012; Sautman and Yan 2014). I continue to argue for this second position in this paper, showing that despite challenges posed by some members of the African Diaspora and some members of the Chinese Diaspora, these Africans in China and Chinese in Africa are playing positive socio-economic, socio-political, and socio-cultural roles, even if sometimes unconsciously, towards strengthening Africa-China cooperation.

\section{Soft power}

These positive socio-economic and socio-cultural contributions by Africans in China may be seen as the basis of a nascent African soft power in China. Soft power is a notion that has become very important in the second decade of the $21^{\text {st }}$ Century Africa-China relations. There are many definitions and conceptualisations of soft power (Nye 1990a\&b, 2004; Bodomo 2009; King 2013). For instance, Joseph Nye, the scholar who first used the term, described soft power or co-optive power in the following terms:

"The second aspect of power - which occurs when one country gets other countries to want what its wants - might be called co-optive or soft power in contrast with the hard or command power of ordering others to do what it wants". (Nye 1990b:166).

It goes further to state:

"Co-optive power is the ability of a country to structure a situation so that other countries develop preferences or define their interests in ways consistent with its own. This power tends to arise from such resources as cultural and ideological attraction as well as rules and institutions of international regimes". (Nye, 1990b:168).

In this study I conceptualise soft power a bit differently as being the gamut of positive socio-political and socio-cultural influences a polity and its citizens have on another polity and its citizens without the threat of "gun-boat" diplomacy or even 
AFFAIRS

outright violence. This definition captures the original core idea of soft power, as a mostly, though not always, an asymmetrical system in which polities use alternative means other than traditional balance of power politics - as regulated mainly by military superiority - to positively influence other polities. It however puts the emphasis on ordinary African citizens consciously or unconsciously acting on behalf of their polities to promote positive views of their countries and continent. How and in what ways have Africans in China employed their positive contributions to Chinese society as a means to increase African soft power, to attain socio-cultural positive views and outlook of Africa in China?

Based on extensive fieldwork in China, using a mixed mode of qualitative and quantitative socio-cultural research methods, I draw on the theoretical notions of soft power and of Diaspora communities acting as bridges interconnecting host and source communities to illustrate this notion of positive Diaspora contributions to Africa-China co-operation. Section 2 sketches the challenges involved; sections 3 and 4 outline some contributions, with the latter focusing empirically on the contributions of two prominent Africans in China; section 5 makes some recommendations for FOCAC support of people-to-people relations; while section 6 summarises the points raised and draws some conclusions to buttress the argument made in the paper.

\section{Africa-China relations: the diaspora challenge}

On July 16, 2009, The South China Morning Post (SCMP), Hong Kong's main English-language newspaper, had on its front page a bold headline and a picture of Africans in Guangzhou demonstrating against police brutality on members of the African community ${ }^{1}$. This was one of the very first times, if not the first, that many people in China and worldwide came to the realisation that there now reside sizeable groups of Africans in Guangzhou and other cities in China such as Hong Kong, Macau, Yiwu, Shanghai and, of course, Beijing. Since then many more negative news reports (but also positive ones) have appeared in Chinese and International news media such as China Daily, CNN, BBC, CCTV, and The New York Times. Most of these reports centre on what has come to be known as the three immigration 


\section{AFRICAN \\ EAST-ASIAN \\ AFFAIRS \\ THE CHINA MONITOR}

illegalities (san fei in Chinese): illegal entry, illegal stay, and illegal engagement in employment. Alongside these media reports are academic writings (for example Zhou 2011) which, based on what are called "perception studies" or even "attitude studies", document instances of negative attitudes and opinions that Chinese have about their African hosts in cities like Guangzhou.

With respect to Chinese in Africa, the two most prominent instances of negative media reports come from Chinese in Zambia, with regards to the ill-treatment of workers by Chinese bosses ${ }^{2}$ and Chinese in Ghana, with regards to illegal immigration, illegal stay, and more prominently, illegal employment activities in the mining sector as reported in several international news media ${ }^{3}$. Besides these prominent cases on Chinese in Africa, there are numerous other reports about Diaspora Chinese indulging in other negative activities such as selling fake medicines, poaching, and undercutting prices to outcompete local businessmen.

If one were to stay with these scenarios of negative reports and their academic analyses, one would find that our target Diaspora communities serve as great challenges and indeed a huge distraction for building more harmonious relations between Africa and China. However, this picture of negativity is far from complete, as we see in the next section of the paper.

\section{Africa-China cooperation: the diaspora contributions}

Diaspora communities, given the definition as presented above and by most prominent scholars of global Diaspora studies throughout the world (for example Vertovec 1997), if presented with the right conditions, have often served as vital links between source and host communities. In several works (Bodomo 2010, 2012; Bodomo and Ma, 2012; Bodomo and Silva,2012), I have developed a theoretical framework showing that Africans in China serve as link points between Africa and China. Africans in Africa and Africans arriving newly in China learn about the Chinese in large part through Africans already in China. Chinese, for their part, learn a lot about Africa, whether negatively or positively, through their interactions with Africans in China. In the same vein, Africans in Africa learn a great deal about China and the Chinese by interacting with Chinese in Africa, and Chinese in Africa 
AFFAIRS

teach their fellow Chinese in China a great deal about Africa and indeed serve as some of the first points of contact for newly arriving Chinese in Africa. In short, Diaspora Africans in China and Diaspora Chinese in Africa function as bridges interconnecting Africa and China in many respects. We may outline three main perspectives to illustrate this bridge theory of migrant-indigene relations: socioeconomic, socio-political, and socio-cultural.

\section{Socio-economic contributions}

Socio-economically, Diaspora Africans and Diaspora Chinese serve as prominent actors in cementing economic relations, frameworks, and platforms between Africa and China. They serve as traders, investors, and remitters.

Many of the Africans in China are traders. They know more than most people what their people back home in Africa need, so they select and source out the most appropriate goods from Chinese factories for the African market; some of them have graduated into investors, starting up their own shipping and even manufacturing companies, sometimes in conjunction with Chinese businessmen to manufacture goods including textiles, household utensils, and farm equipment for the African market and worldwide. Africans remit a substantial amount of money back home to their families in Africa. Says the Chairman of the Guinea Association in Guangzhou:

"Hi Professor, the amount sent home is often a function of many factors: how much the person is getting here on average, how the person's family is organised back home, etc. In general, an adult [male] Guinean in GZ [Guangzhou] has a wife (or wives) and kids back home in Conakry, the capital (or another big town), and his parents and other relatives (his and his wife's/wives' relatives) staying in the villages. It is normal for all these people to be supported by the adult living in GZ. Moreover, it is the ambition of each Guinean in the diaspora to build a house (where he can return) and start a business (shop or plantation, etc.) while still abroad. So, a guestimate for average remittances between 25000Rmb and 150000 Rmb per year is in place".

If all the half a million Africans plying their business in China were doing this, 
Africans in China would be sending anywhere between five and 50 billion yuan a year or more - and this doesn't even include the value of all the merchandise that they buy from China and send back to Africa for sale, which even if not countered as remittance, still constitutes a good contribution from Diaspora Africans in terms of trade. Worldwide, the global African Diaspora sent back to Africa 52 billion dollars in 2010, according to the World Bank, far more than the 43 billion dollars of Overseas Development Assistance (ODA) to Africa in that year. Indeed the African Union (AU) recognises and defines the global African diaspora in terms of the contributions it expects it to make to African development (Edozie, 2012).

Though the focus of this paper is on African soft power in China, it needs to be mentioned for comparative purposes that Chinese in Africa are also performing similar functions as their African counterparts. Much of the Chinese presence in Africa in terms of trade is undertaken by private Chinese businessmen resident in Africa, and many scholars have reported on small scale Chinese enterprises dotted all over the 50-odd African countries- be it in Lesotho, Gabon, Nigeria or Senegal. In terms of investment, many private companies are being started up throughout Africa by individual Chinese resident in Africa. Chinese restaurants are dotted throughout Africa; these private businesses complement the government businesses led by the top 10 Chinese investment companies in Africa including Sinopec, China National Petroleum, State Grid Corporation, Industrial and Commercial Bank of China, China Railway Construction, Sicofor (Sino Congo Foret), CITIC-CRCC, China International Fund (CIF), China State Construction Engineering Corporation Limited (CSCEC), and Federated Steel (Bodomo, 2013).

\section{Socio-political contributions}

In performing these economic activities, Diaspora Africans and Diaspora Chinese also invariably perform socio-political functions. A number of African diplomatic personnel have told me at informal meetings and gatherings how essential some prominent members of the African communities in China are in helping them perform their official consular duties away from Beijing in places like Guangzhou, Yiwu, and Hong Kong. For instance, the office of the Chairman of the Nigerian 
AFFAIRS

Association in Guangzhou was a de facto consulate for many Nigerians and even other Africans during much of the period of my field research in Guangzhou (2008 to present). African community leaders have met there to strategize and resolve immigration problems involving their fellow Africans. Many visiting political and business leaders have sought out established members of the African communities in Hong Kong, Macau, Guangzhou, and Shanghai for support to perform their duties. Some African community members have served as consultative and advisory committee members at the ruling Community Party meetings in Yiwu and other municipalities.

Chinese community members in Africa, while generally shying away from overt dealings with the political establishment in their country of residence and even with their own embassy and government back in China, are mediating political contacts between their members and African governments, especially in times of crises. The situation needs to be investigated more closely in each country. For instance, in the case of Ghana, when a group of alleged illegal miners were arrested and faced deportation, community leaders emerged from their ranks to mediate with the Ghanaian government ministries involved and also to galvanise their members into a pressure group demanding that their Embassy and their government back in China intervene to resolve the problem in their favour. Some members of the Chinese Diaspora continue to develop socio-political links with Africa even when they are back in China. A case in point is a one-time Honorary Consul of Ghana in Hong Kong (the late Jonas $\mathrm{Wu}$ ) who lobbied to be appointed to the position on returning to Hong Kong from an extended stay in Ghana.

\section{Socio-cultural contributions}

Socio-culturally, Africans in China and Chinese in Africa serve as cultural ambassadors, whether consciously or unconsciously, to showcase and promote their cultures in the societies in which they live. Africans in China and Chinese in Africa are learning each other's languages and ways of communicating. Africans in China are becoming more and more proficient in Chinese and even in the various local dialects of the cities in which they live, such as Cantonese in Guangzhou, Hong 


\section{AFRICAN \\ EAST-ASIAN \\ AFFAIRS

Kong, and Macau. In a survey of more than 700 Africans throughout China (Bodomo 2012) more than 50 per cent considered that they spoke Chinese at least only 'a little', with more than 10 per cent being confident that they spoke it very well. We need more of such sociolinguistic surveys to ascertain the levels of language proficiencies in these Diasporas. Two interesting linguistic phenomena that I noticed in Guangzhou are that Chinese who trade and interact with Africans in various ways are beginning to speak English with quite audible African accents and African ways of structuring their vocabularies and communication patterns. A second salient way, described at length in Bodomo (2012) is the phenomenon of calculator communication in which Africans and Chinese who do not share a specific lingua franca like English and Chinese communicate together with the help of a calculator.

Beyond matters of language, Africans in China are creating cross-cultural spaces like ethnic restaurants, barbershops, football clubs, and small quasi-religious groups for worship and social networking, and are organising cultural programmes to showcase African culture like music, drumming, and dancing.

Chinese in Africa are also beginning to learn the official languages of the countries in which they live, like English, French, Portuguese, and Arabic, along with prominent local lingua franca like Swahili, Hausa, Zulu, Amharic, Yoruba, Akan, Bambara, and Wolof. What is needed are comprehensive sociolinguistic surveys among members of the Chinese communities to get more specific linguistic profiles and repertoires to gauge the level of acculturation going on among Chinese communities in Africa, just as done in Bodomo (2012) for Africans in China. Beyond linguistic issues, Chinese in Africa are instrumental in getting Africans to have a taste of Chinese culture through their business activities in matters of cuisine and health, among others. Chinese restaurants are now dotted throughout the cities and towns in all the 50-odd countries of Africa. The African middle class is beginning to consume Chinese medicinal products, such as herbal tea, and awareness about Chinese culture is likely to increase because of the increasing presence of Chinese in Africa and also because of the spread of Chinese media like CCTV and China Daily. 
AFFAIRS

\section{Case studies}

Many of the over 500,000 Africans in China have lived exemplary lives, some have even excelled in various ways to the extent that they have been recognised by the communities in which they live as deserving of awards. In this case study, I focus on two African males. In terms of methodology towards collecting and collating this data, I searched many internet fora and selected these two as Africans that have been broadly acknowledged by their communities. Then I contacted them and they kindly agreed to have me administer questionnaires to both of them; I followed up with a face-to-face interview with one of them on the side-lines of a conference in Paris in May 2014, and did email chatting with the other one to complement the information I collected from the questionnaire ${ }^{4}$. I shall in the following sub-sections summarise the profile of each of these two African soft power brokers in China, as one may call them.

\section{Dominique Saatenang: an African Bruce Lee}

Dominique Saatenang is a Cameroonian by nationality and was in his late $30 \mathrm{~s}$ at the time of my interview. He says that the Chinese call him the African Eagle, the Europeans call him the Black Chinese while the Africans call him the African Bruce Lee. Equipped with an MBA degree, he considers himself as primarily a businessman and a Wushu master, having trained at the Shaolin Wushu Temple in China $^{5}$. He is quite multi-lingual, mentioning French as his native language and other languages spoken as Chinese, English, and Bamileke. Dominique has lived for eight years in China at Defeng, Zhengzhou (Shaolin Temple), and in Beijing (at the Beijing Sports University).

In terms of goodwill and charity, activities that have attracted attention to him are his excellent performance in sports at the Shaolin Temple and the Beijing Sports University. He lists a number of prizes and achievements to his credit, having won many exceptional medals in Wushu practice, including the 2006 Double Vice-World Champion award in Wushu organised in China. He mentions that in 2009, he won a UNESCO medal for his exceptional activities in Wushu; and that in 2011, he won a World Prize for his movie "Bring Charm to China"; and that in that year he was 
AFRICAN

EAST-ASIAN

AFFAIRS

officially named Wushu ambassador of the Shaolin Temple by the Spiritual Chief of the Temple. As charity activities, he mentions that he has brought 10 Africans to study in China for free during his five years at the Shaolin Temple. Asked if he had any ideas about how good African image can be promoted worldwide, he said: "We must just ty to be the best for what we come to do in China in our chosen activities".

\section{Adam Musa: an African Lei Feng}

Adam Musa was a 29-year old PhD student in International Relations at Central China Normal University in Wuhan Hubei Province, China at the time of my interview. He is a Nigerian national and his mother tongue is Hausa, and he lists languages such as English and Mandarin Chinese as other languages that he speaks. Altogether, he has spent six years in China and outside Nigeria. Adam has excelled in many charity events, including blood donation for three years at the time of the interview, visiting houses for the elderly to help them, visiting orphanages, and volunteering as a teacher for migrant workers' schools since 2010. He mentions that he has also been involved in many environmental protection exercises code-named "Keep Wuhan Clean".

Adam is a highly decorated community activist. To the question: "Have you won any prizes or been recognised in any way by the community or local authorities?", he provides the following impressive list:

2011 Central China Normal University Excellent student Award

2011 Hubei province University Students Excellent Award

2012 Hubei Province Excellent Social Work Award

2012 China Youth Volunteer Excellent Award

2013 Central China Normal University Excellent Talent Award

2014 International Cultural Exchange Friendship Award

Indeed, Adam's work has been widely recognised and talked about in the community, and he has been featured in many Chinese media such as the China 


\section{Daily ${ }^{6}$.}

When it was his turn to answer the question if he had any ideas about how good African image can be promoted worldwide, he said "[a] good African image can be promoted worldwide by Africans wherever they are being law-abiding, [and] they should respect and conform to laws of the society in which they find themselves. They should also engage more in the promotion of community development activities."

\section{Summary}

These case studies have illustrated - by concentrating on two Africans widely recognised in Chinese society as extraordinary members of the community - that Africans are contributing to the promotion of socio-cultural relations between Africa and China. These two and many other Africans located in many places in China including Guangzhou, Hong Kong, Macau, Yiwu, Shanghai and Beijing are emerging as agents of African soft power in China.

\section{Discussion: an alternative hypothesis?}

In this section, we address a few other issues that go to contextualise the case studies involving these two African individuals and then pose the question whether we are indeed dealing with African soft power or there could be an alternative hypothesis at work that claims that this is rather a manifestation of Chinese soft power ${ }^{7}$.

The first issue is how the skills of the two individuals are related to conditions in China. Their skills including martial arts, volunteering, care for one's neighbours and proficiency at several languages all relate to the Chinese socio-cultural conditions, and are much appreciated by the Chinese as people. A second issue is what cultural framework the decorated individuals are seen to be excelling in. Even though they lived in China at the time of the study, I believe that they excel in both African and Chinese cultural frameworks, and even beyond. One of them got a UNESCO prize these are individuals who have demonstrated universal values of charity and selflessness! It cannot therefore be the case that these individuals are influenced only by the Chinese cultural framework to do good. They are in China, so they have to 


\section{AFRICAN \\ EAST-ASIAN \\ AFFAIRS

operate in this framework, but it is not only the Chinese who are appreciating them, Africans are also appreciating them - one of them brought 10 Africans to study in China; these individuals surely appreciate that gesture. A third issue also has to be raised as to what specific benefits Africa is getting for the excellence these Africans are demonstrating in China. This must be seen, not in terms of monetary gains, but in terms of enhancing Africa's image in China. Africa's image is very often gutted in China by the frequent tensions and clashes between Africans in China and mostly law-enforcement authorities and these specific positive contributions by the Africans would go a long way to changing the mentality of some Chinese citizens about Africa. Fourthly, it must be mentioned that these individuals are not just demonstrating exclusively Chinese cultural values or exclusively African cultural values. Rather, they possess some important cross-cultural nuances or even universal values: hard work, generosity (in terms of giving out their money and time), a caring nature, valour, and so on! Finally, the question arises as to why we have limited ourselves to only two individuals. It is because these are case studies; the author is embarking on a series of articles on soft power and cannot document a throng of African individuals in one paper, even if their ethnographic profiles were readily available.

In sum then, many of the issues raised in this section may lead to an alternative hypothesis that postulates that these individuals, rather than being conduits of African soft power in China, are indeed demonstrating that they have been imbued with Chinese soft power; in other words, that it is Chinese soft power, rather than African soft power, that is at play here because the Chinese are somehow only appreciating these Africans as a way of infusing Chinese soft power in them, rather than having a positive view of Africa because of the activities of these individuals.

Several issues may be at play here that do not in any way negate the hypothesis of African soft power as argued throughout the paper, and must therefore be teased out.

First, it is plausible that the Chinese admire these individuals for learning Chinese culture and speaking the Chinese language very well - but so do they do with regards to other Africans who have learnt Chinese culture and speak the Chinese language 
AFFAIRS

fluently. It is not everybody who so integrates themselves into Chinese society who are awarded such high prizes. These individuals are bringing something else to the table, and that extra something is the basis of the African soft power as argued here. The two individuals (and many more that could be uncovered through further research) are excelling in terms of their volunteerism, kindness, generosity, valour at Wushu, and intelligence and the Chinese see many of these as attributes they brought from Africa and thus have a positive view of these Africans. This is clearly in line with aspects of our earlier definition of soft power as "...the positive...socio-cultural influences a polity and its citizens have on another polity and its citizens....". If we found Chinese in Africa of the same stature as these Africans in China, there would be no doubt that they would be seen as spreading Chinese soft power, so there is no reason to doubt that these Africans are spreading African soft power in China.

Second, it may be the nature of soft power such that when it is deployed in one direction, there could be a reciprocal effect; that is, soft power effects of entity A unto entity B may engender soft power effects of entity B unto entity A, though not always. Soft power can be symmetrical and bidirectional, unlike hard power, which is necessarily asymmetrical and unidirectional. Seen this way, even if the Chinese are preoccupied with trying to infuse Chinese soft power into these individuals, they are in turn getting infused with African soft power, as they cannot help but admire these individual Africans and the attributes they may have brought from Africa. So, the hypothesis of an African soft power, rather than being negated, is indeed strengthened.

\section{Looking ahead: recommendations for a people-to-people approach}

We have demonstrated in the above analysis that Diaspora African communities in China and Diaspora Chinese communities in Africa act as vital economic, political, and cultural links - bridges - between Africa and China, and especially that a good number of Africans in China are engaging in activities that go to form the building blocks of an emergent African soft power in China. This soft power building process may be occurring among Chinese in Africa and awaits a closer investigation. It therefore goes without saying that if we are looking for ways to strengthen Africa- 
China co-operation, we must involve Diaspora Africans and Diaspora Chinese. I recommend that while the first decade of the co-operation was more of a government -to-government approach, which was necessary to create a solid base, the second decade should be dedicated to strengthening a people-to-people approach to AfricaChina cooperation. A people-to-people approach involves creating avenues for different groups of people from each side of the partnership, like professional associations, academic groups, business groups, youth and student movements, artists, and sportsmen to interact more often. Diaspora community members can play a vital role in facilitating contact between all these groups mentioned, since they are indeed already doing this on their own and are sitting with a lot of experience about contacts at all the levels.

The $5^{\text {th }}$ edition of the Forum on Africa-China Cooperation (FOCAC2012 in Beijing) did touch briefly on the idea of people-to-people relations, presumably based on the exhortations some of us scholars have already been making through our writings, but it did not actually stress it enough, and said very little about what we could do to achieve it. I recommend that the $6^{\text {th }}$ edition (FOCAC2015 in South Africa) should dedicate a whole working session and theme on the role of the two Diasporas involved in the partnership to find out how we can enhance their formal participation in strengthening Africa-China cooperation if they so wish.

Two ways in which we can enhance their participation is, first, by streamlining immigration rules on both sides of the partnership. There must be clearer paths to permanent residency and citizenship for Africans in China and Chinese in Africa. Police and other security forces on both sides of the partnership must respect the rights of Diaspora members, including treating even those on the wrong side of the law, such as African visa over-stayers in Guangzhou or Chinese illegal miners in Ghana, humanely.

A second way is to create structures and incentives to get Diaspora Africans and Diaspora Chinese keenly interested in strengthening Africa-China cooperation. Funds can be set aside for competitive bidding by various Diaspora Community groups to be used in promoting cultural activities that go towards enhancing the intermingling of Africans and Chinese. It is now time for governments on both sides 
AFRICAN

EAST-ASIAN

AFFAIRS

THE CHINA MONITOR

of the partnerships to start promoting Diaspora cultural festivals, Diaspora business meetings, academic conferences on the African and Chinese Diasporas, and Diaspora Sports festivals. There should also be reward and recognition systems to highlight excellence in service and leadership among Diaspora community members on both sides of the partnership.

\section{Summary and conclusions}

As Africa and China move closer to each other for mutual benefits, Diaspora communities will grow on each side of the partnership. Media and academic reports and analyses are documenting both negative and positive activities involving members of these Diaspora communities, suggesting that the communities that are the subject of this study can indeed be double-edged swords, in that their activities can pose both challenges and opportunities to the development of Africa-China relations. I have argued here that, after balancing things out, the Diaspora account is indeed in the positive digits since the communities in question play far more positive than negative roles in strengthening Africa-China co-operation. Many members of the African communities in China are indeed engaging in activities that may go to promote the good image of Africa in China, and may indeed be building the bricks for an African soft power in China. This may well be the case for Chinese in Africa, and this needs further investigation.

If the recommendations outlined above are implemented, Diaspora Africans in China and Diaspora Chinese in Africa can serve as agents of soft power that promote cultural diplomacy, and as useful links or bridges to the further development of Africa-China cooperation.

\section{Endnotes}

1. The SCMP article was titled: "Africans protest in Guangzhou after Nigerian feared killed fleeing visa check" SCMP, July 16, 2009: http:// www.scmp.com/article/686919/africans-protest-guangzhou-after-nigerianfeared-killed-fleeing-visa-check (accessed: August 19, 2014). 
AFRICAN

2. Lusaka News. 9 October 2010. Ill-treatment of workers, disgraceful - ZFE [Online]. Available: http://www.lusakatimes.com/2010/10/19/illtreatmentworkers-disgraceful-zfe/ (2014, August 19).

3. BBC News. June 6, 2013. Ghana arrests Chinese for 'illegal mining' [Online]. Available: http://www.bbc.co.uk/news/world-asia-china22793659 (2014, August 19).

4. The criteria for inclusion were quite stringent: for anyone to be on my list they had to have won a recognition in the society in which they were operating. This is a case study and if the research is pushed further other individuals, including females, would show up.

5. A video clip of his activities as a Wushu practitioner can be viewed at this youtube link: https://www.youtube.com/watch? $\mathrm{v}=\mathrm{oXGYsN-VLdY}$

6. China Daily has one of several reports on Adam Musa, the latest being an article titled: "Lei Feng's African brother" (Lei Feng being 'China's icon of selflessness' at this weblink: http:/usa.chinadaily.com.cn/epaper/2013-08/06/ content_16874364.htm, China Daily Aug 6, 2013 (accessed on August 19, 2014)

7. I thank an anonymous reviewer for suggesting this alternative hypothesis.

\section{Bibliography}

Bodomo, A. 2014. The African traveller and the Chinese customs official: Ethnic Minority Profiling in Border Check Points in Hong Kong and China? Journal of African American Studies. New York: Springer Science and Business Media.

Bodomo, A. 2013. The Globalization of Investment: Chinese Companies in Africa, Modern Ghana [Online]. Available: http://www.modernghana.com/ news/444094/1/the-globalization-of-investment-chinese-companies-.html 
AFRICAN

EAST-ASIAN

AFFAIRS

[2015, June 30].

Bodomo, A. 2013. African Diaspora Remittances are Better than Foreign Aid Funds. World Economics, 14(4):21-28.

Bodomo, A. 2012. Africans in China: A Sociocultural Study and Its Implications for Africa-China Relations. Amherst, New York: Cambria Press.

Bodomo, A. 2010. The African trading community in Guangzhou: an Emerging Bridge for Africa-China relations. China Quarterly, 203:693-707.

Bodomo, A. 2009. Africa-China relations: Symmetry, Soft Power, and South Africa. The China Review: An Interdisciplinary Journal on Greater China, 9(2):169178.

Bodomo, A. and Ma, G. 2012. We Are What We Eat: Food in the Process of Community Formation and Identity Shaping Among African Traders in Guangzhou and Yiwu. African Diaspora, 5(1):1-26.

Bodomo, A. and Ma, G. 2010. From Guangzhou to Yiwu: Emerging facets of the African Diaspora in China. International Journal of African Renaissance Studies, 5(2):283-289.

Bodomo, A. and Silva, R. 2012. Language Matters: The Role of Linguistic Identity in the Establishment of the Lusophone African Community in Macau. African Studies, 71(1):71-90.

Bork, T., Rafflenbeul, B., Kraas, F., and Li, Z. 2011. Global Change, National Development Goals, Urbanization and International Migration in China: African Migrants in Guangzhou and Foshan, in Kraas, F., Aggarwal, S., Coy, M.,and Mertins, G. (eds.). Megacities: Our Global Urban Future. Dordrecht; New York; London: Springer.

Bredeloup, S. 2012. African Trading Posts in Guangzhou: Emergent or Recurrent Commercial Form? African Diaspora, 5(1):27-50.

Castillo, R. 2014. Feeling At Home in the "Chocolate City": An Exploration of Place 
AFRICAN

-Making Practices and Structures of Belonging Amongst Africans in Guangzhou. Inter-Asia Cultural Studies, 15(2):1-23.

Cissé, D. 2013. South-South Migration and Sino-African Small Traders: A Comparative Study of Chinese in Senegal and Africans in China. African Review of Economics and Finance, 5(1):17-30.

Edozie, R. 2012. The Sixth Zone: The African Diaspora and the African Union's Global Era Pan Africanist. Journal of African American Studies, 16(2):268299.

Hall, B., Chen, W., Latkin, C., Ling, L., and Tucker, J. 2014. Africans in South China Face Social and Health Barriers. The Lancet, 283(9925):1291-1292.

Han, H. 2013. Individual Grassroots Multilingualism in Africa Town in Guangzhou: The Role of States in Globalization. International Multilingual Research Journal, 7(1):83-97.

Haugen, H. 2013. African Pentecostal Migrants in China: Marginalization and the Alternative Geography of a Mission Theology. African Studies Review, 56 (1):81-102.

Haugen, H. 2012. Nigerians in China: A Second State of Immobility. International Migration, 50(2):65-80.

Haugen, H. 2011. Chinese Exports to Africa: Competition, Complementarity and Cooperation between Micro-Level Actors. Forum for Development Studies, 38(2):157-176.

King, K. 2013. China Aid and Soft Power in Africa: The Case of Education and Training. Suffolk: James Currey.

Lan, S. 2014. State Regulation of Undocumented African Migrants in China: A Multi-Scalar Analysis. Journal of Asian and African Studies, 5:1-16

Li, Z., Ma, L., and Xue, D. 2009. An African enclave in China: The Making of a New Transnational Urban Space. Eurasian Geography and Economics, 50 
AFRICAN

EAST-ASIAN

AFFAIRS

(6):699-719.

Li, Z., Lyons, M., and Brown, A. 2012. China's 'Chocolate City': An Ethnic Enclave in a Changing Landscape. African Diaspora, 5(1):51-72.

Lyons, M., Brown, A., and Li, Z. 2013. The China-Africa Value Chain: Can Africa's Small-Scale Entrepreneurs Engage Successfully in Global Trade? African Studies Review, 56(3):77-100.

Lyons, M., Brown, A., and Li, Z. 2012. In the Dragon's Den: African traders in Guangzhou. Journal of Ethnic and Migration Studies, 38(5):869-888.

Lyons, M., Brown, A., and Li, Z. 2008. The 'Third Tier' of Globalization: African traders in Guangzhou. City, 12(2):196-206.

McLaughlin, M. M,, Lee, M. C., Hall, B. J., Bulterys, M., Ling, L., and Tucker, J., D. 2014. Improving Health Services for African Migrants in China: A Health Diplomacy Perspective. Global Public Health, 9(5):579-89.

Mathews, G. and Yang, Y. 2012. How Africans Pursue Low-End Globalization in Hong Kong and Mainland China. Journal of Current Chinese Affairs, 41 (2):95-120.

Mohan, G. and Lampert, B. 2013. Negotiating China: Reinserting African Agency into Africa-China relations. African Affairs, 112(446):92 - 110.

Nye, J. 2004. Soft Power: The Means to Success in World Politics. New York: Public Affairs.

Nye, J. 1990b. Soft Power. Foreign Policy, 80:153-171.

Nye, J. 1990a. Bound to Lead: The Changing Nature of American Power. New York: Basic Books.

Park, Y. 2008. A Matter of Honour: Being Chinese in South Africa. Lanham: Lexington Books/Rowman \& Littlefield Publishers.

Pieke, F. N. 2012. Immigrant China. Modern China, 38(1):40-77. 
AFRICAN

Sautman, B. and Hairong, Y. 2014. Bashing 'The Chinese': Contextualizing Zambia's Collum Coal Mine Shooting. Journal of Contemporary China, 23 (90):1073-1092.

Wyatt, Don J. 2010. The Blacks of Premodern China. Philadelphia: University of Pennsylvania Press.

Yang, Y. 2013. African Traders in Guangzhou, in Mathews, G., Ribeiro, G. L., and Vega, C. A. (eds.). Globalization from Below: The World's Other Economy. London, New York: Routledge.

Vertovec, S. 1997. Three Meanings of 'Diaspora,' Exemplified Among South Asian Religions. Diaspora, 6(3):277-299.

Zhou, M. 2011. Meeting Strangers in a Globalized City: Chinese Attitudes Towards Black Africans in Guangzhou, China [Online]. Available: http:// www.fe.hku.hk/chinaed/sem_poster/Zhou_HKU_June2011.pdf [2015, June 30]. 


\section{AFRICAN \\ EAST-ASIAN \\ AFFAIRS}

